\title{
Does Comprehensive Income Predict Future Cashflow Better Than Net Income?
}

\author{
BAYU SETYAWAN SUPRAYOGI \\ ZUNI BAROKAH \\ Universitas Gadjah Mada
}

\begin{abstract}
This study examines the ability of net income and comprehensive income in predicting future cash flows on publicly listed companies in Indonesia Stock Exchange. Further, this study also compares the ability of net income and comprehensive income in predicting future cash flows. Based on the sample of 1,735 firm-year observations of Indonesian listed companies for the financial years of 2011-2016, the result shows that both net income and comprehensive income have a significant relationship with future cash flows. However, we find that comprehensive income does not have a better capability than net income in predicting future cash flows.
\end{abstract}

Keywords: Net income, comprehensive income, future cash flows

Abstrak: Penelitian ini menguji kemampuan laba bersih dan pendapatan komprehensif dalam memprediksi arus kas masa depan pada perusahaan publik di Bursa Efek Indonesia. Selanjutnya, penelitian ini juga membandingkan kemampuan laba bersih dan pendapatan komprehensif dalam memprediksi arus kas masa depan. Berdasarkan sampel dari 1.735 pengamatan tahun-perusahaan dari perusahaan publik Indonesia untuk tahun keuangan 2011-2016, hasilnya menunjukkan bahwa laba bersih dan pendapatan komprehensif memiliki hubungan yang signifikan dengan arus kas masa depan. Namun, kami menemukan bahwa pendapatan komprehensif tidak memiliki kemampuan yang lebih baik daripada laba bersih dalam memprediksi arus kas masa depan.

Kata kunci: Pendapatan bersih, pendapatan komprehensif, arus kas masa depan

\section{Introduction}

The financial statement aims to provide financial information of an entity to investors or creditors that can be used for decision making regarding capital allocation (FASB, 2010; IASB, 2010). Useful information in decision making must meet the qualitative characteristics of fundamental relevance (IAI, 2017). Relevance is the ability 
of information to assist the users of financial statements in distinguishing some alternative decisions, so there are several choices of decisions that can be taken (Suwardjono, 2005). Relevant information must have a predictive value that is capable of estimating some of the pop-ups from past, present, and future events.Decisionmaking such as selling, buying, or holding stocks can be done when the user's financial statements can determine the value of a company. The value of a company can be seen from its share. At first, the value of the company's shares can be measured using the future dividend function (Gordon, 1962). However, the uncertainty of dividend distribution opens. Another alternative opportunity in the valuation of the company's shares, namely using the function of future cash flows (Brigham, Houston, Jub-Ming, Kee, and Ariffin, 2013). Therefore, users of financial statements need to be able to assess the performance of an entity in generating future cash flows.

One of the financial statements that can be used to demonstrate that the company's performance is a comprehensive income statement. Also, comprehensive income statements relate to the ability of a company to produce cash flows in the future. Comprehensive income statements can be used to predict future cash flows of an enterprise (Kieso, Weygandt, and Warfield, 2014). Previous research conducted by Oleh Palea and Scagnelli (2016) and Kim and Kross (2005) proved that the accrual profit has a significant ability to predict future cash flows.

As a member of the G20 Forum, Indonesia is obliged to implement IFRS as its financial reporting standard. Indonesia conducts the IFRS in gradually; it is performed in PSAK 1 revision 2009, which will be effective as of 1 January 2011. In such revisions, it was disclosed that a comprehensive income statement should contain other comprehensive income information. Other comprehensive income coupled with net profit will constitute a comprehensive profit. At SFAC 8 It is revealed that comprehensive income is expected to provide complete information about the company's performance (FASB, 2010). As such, there are two types of profits reported in the comprehensive income statement, i.e., net income and comprehensive profit.

Several previous studies have revealed different outcomes regarding the ability of comprehensive profit and net profit in predicting future cash flows. Dhaliwal, 
Subramanyam, and Trezevant (1999) proved that comprehensive income has no better ability than net profit in predicting the price of stocks and future cash flows. Jaweher and Mounira (2013) found that net profit has higher value relevance than comprehensive profit in explaining future cash flows and future profits. Palea and Scagnelli (2016) found that comprehensive income has better abilities than net profit in predicting future cash flows. The motivation of this research is to know the benefits of additional other comprehensive income information on net income to form a comprehensive profit in predicting future cash flows.

\section{Review of The Literature and Hypothesis Development}

\subsection{Prior Literature}

Dhaliwal, Subramanyam, and Trezevant (1999) researched to prove the advantages of comprehensive profit on net profit in assessing the company's performance. The company's performance assessment can be measured with the relevance of the accrual profit value with the share price, future cash flow, and future accrual profit. The study used 11,425 company observations in 1994-1995 that came from the COMPUSTAT and CRSP data. By issuing companies in the financial industry, the study proved that comprehensive income has no greater value relevance than net profit.

Kim and Kross (2005) tested the ability of accrual profits in predicting the cash flow of operations one year into deposits from 1973 to 2000. He used 100,622 observations taken from the industrial Compustat. The study proved that the accrual profit in the current year is associated significantly with the operating cash flow of one year ahead. Also, there has been an increase in accrual profitability to explain future cash flows over time.

Chambers, Linsmeier, Shakespeare, and Sougiannis (2007) conducted research on the emergence of the SFAS 130 on the disclosure of comprehensive earnings to companies listed in the S \& P 500 index from 1994 to 2003. The study showed that the disclosure of other comprehensive income information provided after the presence of SFAS 130 has higher value relevance compared to such disclosure before the SFAS 130. Atwood Drake, Myers, and Myers (2011) use samples from 33 countries to 
determine the persistence of profit and profitability in predicting future cash flows in countries using IFRS and U.S. GAAP. The results of the study proved that there were no significant differences between the persistence of profit in the countries using IFRS and the US GAAP. Also, profits are now positively associated with future cash flows in both the IFRS and US GAAP countries. US GAAP profit is better than profit based on IFRS in predicting future cash flows. However, the difference in such abilities is not significant. Jaweher and Mounira (2013) conducted research on the relevance of the value of net profit and comprehensive profit. He used samples of 2,271 companies from 22 countries in Europe, Asia, and Australia between 2006 and 2010. The research proves that net profit has better capability than comprehensive profit in predicting future cash flows and future profits.

Palea and Scagnelli (2016) Examine the capabilities of net profit, comprehensive profit, and comprehensive profit broke down into net income and other comprehensive income in predicting future cash flows. The research was conducted in Europe with samples of 1,454 years of termination of the company. The research proves that net profit, comprehensive profit, and comprehensive profit broke down into net income and other comprehensive income can predict future cash flows. In addition, the research proves that comprehensive profit and comprehensive profit broke down into net profit and other comprehensive income have greater capability than net profit in predicting the cash flow.

\subsection{Hypothesis Development}

The change of economic resources and claims to a company reflects the company's accrual profit. IAI (2017) states that accrual profit indicates the extent to which the company can develop the available economic resources and its ability to generate cash flows from operating activities. The basic framework of drafting and presenting the financial statements par. 1.18, IAI (2017) states that accrual profit is beneficial to assess the ability of the company to generate future cash flows.

Kim and Kross (2005) found empirical evidence that the ability of net profit in predicting future cash flows has increased over the past three decades. Atwood et al. (2011) found empirical evidence that net income based ON IFRS, as well as in addition 
TO IFRS, was beneficial to predict future cash flows. Palea Scagnelli (2016) finds empirical evidence that profit has future cash flow prediction capabilities. Based on the statement of an IAI (2017) and the findings of Kim and Kross (2005), Atwood et al. (2011), as well as Palea and Scagnelli (2016) it can be formulated as the following hypothesis:

\section{H1: Net profit level of the company associated with future cash flows}

According to PSAK 1 revision 2009, the income statement should present a comprehensive net income and profit (IAI, 2017). Comprehensive income consists of net income plus other comprehensive income. Before a comprehensive profit, another comprehensive income was in the report on capital change. The additional information of other comprehensive income in comprehensive income is expected to help users of financial statements to assess the company's ability to generate future cash flows (FASB, 2010; IASB, 2010).

Wolk, Dodd, and Rozycki (2013) revealed that comprehensive profit could minimize management manipulation of the decision on the recognition of other comprehensive income components that previously directly influenced the retained earnings balance. It is expected to be useful to know the substantial advantages and disadvantages. The CFA Institute (2015) states that changes in the value of financial position components contained in comprehensive income may indicate a change in the ability of an entity to generate future cash flows. Thus, the comprehensive profit contains information about the condition of changing the company's resources more fully than net profit.

Chambers et al. (2007) prove empirically that other comprehensive income information has value relevance to estimating stock prices. Palea and Scagnelli (2016) found empirical evidence that comprehensive profits, as well as comprehensive profits, were broken down into net income and other comprehensive income had relationships with future cash flows. Additionally, Palea and Scagnelli (2016) found empirical evidence that comprehensive earnings have better capabilities than net profit in predicting future cash flows. According to the statement IAI (2017); FASB (2010), 
IASB (2010); Wolk, DoDD, and Rozycki (2013); Chambers et al. (2007); as well as Palea and Scagnelli (2016), it can be formulated as the following hypothesis

H2: A comprehensive profit level associated with future cash flows.

H3: Comprehensive profit has a better association relationship than net profit in explaining future cash flows.

\section{Reseach Methods}

\subsection{Sample Selection}

This research uses secondary data of pooled cross-section, which is obtained from the Bloomberg database and the audited financial statements available on the IDX website. The population in this research is the entire company listed on the Indonesia Stock Exchange. The selection of samples in this study used the purposive sampling method (Sekaran Bougie, 2016) covering the financial years of 2011 to 2016. Table 1 below presents the selection of samples in this study.

Table 1

Sample Selection

\section{Criteria}

Amount

Total number of companies 3,204

Companies with an incomplete dataset

Observations that have a T-1 net profit value equal to $\mathrm{T}-1$ comprehensive income

Observations used in research

1,735

\subsection{Test Data Analysis}

Net profitability in predicting future cash flows is carried out with the following research models :

$$
A K O_{i t}=\beta_{0}+\beta_{1} N I_{i t-1}+\beta_{2} \text { Tahun }+\beta_{3} \text { Industri }+\varepsilon
$$

Where: $A K O_{i t}=$ Cash flows from the operational activity of the company I in year $\mathrm{t} ; \beta=$ parameter Estimasian; $N I_{I t-1}=$ Net profit of company I in T-1 year; Year= dummy 
variable in the year of observation; Industry= dummy variables in industry type; $\varepsilon=$ error term.

The dependent variable cash flow operations and independent net profit variables used in this study have been divided by the total average assets. This is done to minimize heteroscedasticity (Ole, Kim, and Cross, 2005). The year control variables are used to identify the effect of the year on observations made so that the regression coefficient becomes unbiased (Wooldrige, 2013). While industrial control variables are used to identify the unique characteristics of each industry. The use of this year's control variables and the industry is following previous research conducted by Palea and Scagnelli (2016) and Atwood et al. (2011). In addition, to test the consistency of model 1 carried out regression tests per year and per industry, so that developed models as follows.

$$
\begin{aligned}
& A K O_{i t}=\beta_{0}+\beta_{1} N I_{i t-1}+\beta_{2} \text { Tahun }+\varepsilon \\
& A K O_{i t}=\beta_{0}+\beta_{1} N I_{i t-1}+\beta_{3} \text { Industri }+\varepsilon
\end{aligned}
$$

$\mathrm{P}$ a comprehensive profitability in predicting future cash flows is conducted with the following research models:

$$
A K O_{i t}=\beta_{0}+\beta_{1} C I_{i t-1}+\beta_{2} \text { Tahun }+\beta_{3} \text { Industri }+\varepsilon
$$

Where is the CIIt $1=$ Company's comprehensive profit in the year T-1. Like the variables contained in Model 2, the comprehensive profit variables in the study were divided by the total average assets.

In addition, untick tests the consistency of Model 4, performed regressions per year, and industry so that developed models as follows.

$$
\begin{aligned}
& A K O_{i t}=\beta_{0}+\beta_{1} C I_{i t-1}+\beta_{3} \text { Industri }+\varepsilon \\
& A K O_{i t}=\beta_{0}+\beta_{1} C I_{i t-1}+\beta_{2} \text { Tahun }+\varepsilon
\end{aligned}
$$

To compare the ability of the net profit and comprehensive profit in predicting future cash flows, this research uses the value of the Akaike information criterion (AIC) obtained from Model 1 and Model 2. The AIC value can be known by the following formula. (Burnham \& Anderson, 2004)

$$
\text { AIC }=2 k-2 \ln (\text { likelihood })
$$


Where $\mathrm{AIC}=$ value of Akaike information criterion; $\mathrm{k}=$ number of estimating parameters; ln (likelihood) $=$ is the best value of the result of a regression model estimating. The AIC value indicates the loss of information of a statistical model when used to estimate the actual situation relative to other statistical models. Models that have the smallest AIC value indicate that the model is best relative to other models. To find out how good a model is relative to another model, then it can be used relative value (Burnham \& Anderson, 2004)likelihood with the following formula :

$$
\text { Relative Likelihood }=\exp \left(\frac{A I C_{\min }-A I C_{i}}{2}\right)
$$

Where Relative Likelihood= Comparison of a model to another model; exp= exponential; $A I C_{\min }=$ the smallest AIC value; $A I C_{i=}$ AIC Value of the model I. Additionally, a supplementary analysis of the 3-hypothesis testing in the form of development of the new model by splitting the comprehensive profit information into net income and other comprehensive income. Therefore, developed the research model as follows.

$$
A K O_{i t}=\beta_{0}+\beta_{1} N I_{i t-1}+\beta_{1} O C I_{i t-1}+\beta_{2} \text { Tahun }+\beta_{3} \text { Industri }+\varepsilon
$$

Where $O c i_{I t-1}=$ Another comprehensive income company I was on the year T-1 that has divided the total average assets. It is done to know how much other comprehensive generating information relationship with the cash flow of Mas ahead.

\section{Analysis and Discussion}

\subsection{Descriptive Statistics}

Based on the 1,735 observations, the descriptive statistics of all dependent and independent variables of the study are presented in Table 2.

Table 2 shows the minimum value for all variables is negative, and the maximum value is positive. The same was the case with the research conducted by Palea and Scagnelli (2016). So, the value of the entire variable used ranges from negative to positive. The net profit (-1.7282) variable has a minimum value that is smaller than the comprehensive profit (-1.7274). While the maximum net profit value (0.9514) is higher 
than the maximum value of comprehensive profit (0.8662), so the net profit variable has a distance between the minimum value and the maximum value greater than the comprehensive profit. From this, it can be noted that the addition of other comprehensive income components in net profit can reduce the distance from the minimum value and maximum value on the observation.

Table 2

Descriptive Statistics of Dependent and Independent Variables $(n=1,735)$

\begin{tabular}{l|r|r|r|r}
\hline \multicolumn{1}{c|}{ Variable } & \multicolumn{1}{c|}{ Average } & \multicolumn{1}{c|}{$\begin{array}{c}\text { Standard } \\
\text { deviation }\end{array}$} & Minimum & Maximum \\
\hline${ }^{\prime}{ }_{K O O^{\prime}}$ & 0.0464 & 0.1241 & -1.0022 & 0.9515 \\
$N I_{I T-1}$ & 0.0363 & 0.1269 & -1.7282 & 0.9514 \\
$C I_{I T-1}$ & 0.0444 & 0.1339 & -1.7274 & 0.8662 \\
$O C I_{I T-1}$ & 0.0081 & 0.0458 & -0.3293 & 0.5999 \\
\hline
\end{tabular}

Description: $A K O=$ cash flow operation; $N I=$ net income; $C I=$ Profit comprehensive; $O c i=$ other comprehensive income; $I=$ Company I; $t=\mathrm{t}$ period; $T-I=\mathrm{t}-1$ period.

Further, the addition of other comprehensive income components on net profit can also increase the average value and standard deviation. This is evident from the average net profit (0.0363), which is smaller than the average comprehensive profit (0.044). In contrast, the standard deviation of net profit $(0.1269)$ is lower than the standard deviation of comprehensive profit (0.1339). On the other hand, other comprehensive revenues have an average of 0.0081 , a standard deviation of 0.00458 , a minimum value of- 0.3283 , a maximum value of 0.5999 , and cash flow operating has a minimum value of-1.022; maximum value of 0.9515 , standard deviation 0.1241 ; and average 0.0464 .

\subsection{Hypothesis Testing (H1)}

Cash flow prediction Model with independent variable net income and year and industry control variables presented in the following Table 3.

According to Table 3, the cash flow prediction model 1 has F-statistics of 14,82 $(\mathrm{p}<0.05$ ), so it can be concluded that the regression model deserves use to predict future cash flows. Additionally, the cash flow prediction model 1 has an adjusted value of R2 
of 0.0939. The value indicates that the net profit and control variables used can be used to describe the cash flow of future operations by $9.39 \%$, and the remainder is described by other variables outside of the regression model.

Table 3

Regression Result of Cash Flow Model (Prediction 1)

\begin{tabular}{l|c|c|c}
\hline \multicolumn{1}{c|}{ Model } & Coefficient & Standard Error & $p$-value \\
\hline (constant) & 0.045 & 0.016 & 0.004 \\
$N I_{I T-1}$ & 0.223 & 0.023 & 0.000 \\
\hline$F$-Count $\quad=14.82$ & R-square & $=0.1007$ \\
$P$. Value $=0.000$ & Adjusted $R$-square & $=0.0939$ \\
Effects of years and industries have been controlled
\end{tabular}

Variable bound: $A K O_{i t}$

Description: $A K O=$ cash flow operation; $N I=$ net income; $I=$ Company $\mathrm{I} ; t=\mathrm{t}$ period; $T-I=\mathrm{T}-1$ period.

The net profit variable has a coefficient of 0.223 ( $\mathrm{p}<0.05)$. Thus, H1 is supported. These results were following the research conducted by Kim and Kross (2005), Atwood et al. (2011), as well as Palea and Scagnelli (2016), who revealed that net profit has an association relationship with future cash flows. In addition, these results prove that net profit as information on the resource change an entity can be used to estimate the capabilities of the entity in generating future cash flows. The additional analysis of hypothesis testing 1 with regression tests per year is presented in Table 4 , and a regression test per industry is presented in Table 5.

Table 4

Regression results of future cash flows and net profit per year

\begin{tabular}{lllllll}
\hline Description & & 2012 & 2013 & 2014 & 2015 & 2016 \\
\hline$N I_{I T-1}$ & Coefficient & 0.192 & 0.252 & 0.199 & 0.379 & 0.178 \\
& P. value & 0.000 & 0.000 & 0.000 & 0.000 & 0.000 \\
& Adj. $R$-Square & 0.112 & 0.169 & 0.121 & 0.113 & 0.057 \\
$\mathrm{~N}$ & & 235 & 250 & 261 & 466 & 523
\end{tabular}

The dependent variable cash flow operations and industry variables have been controlled 
Table 5

Results of regression of future cash flows and net profit per industry

\begin{tabular}{llccc}
\hline Description & Key sectors & Manufacturing sector & $\begin{array}{c}\text { Service } \\
\text { sector }\end{array}$ \\
\hline$N I_{I T-1}$ & Coefficient & 0.268 & 0.498 & 0.165 \\
& $P$. value & 0.000 & 0.000 & 0.000 \\
& Adj. $R$-Square & 0.119 & 0.192 & 0.027 \\
$\mathrm{~N}$ & 230 & 466 & 1039 \\
Industry variables have been controlled & & & \\
\hline
\end{tabular}

As shown in Table 4 and Table 5 above, the net profit (NIIt-1) variable from 2012 to 2016 is associated significantly $(\mathrm{p}<0.05)$ with future cash flows. Variable coefficient of net profit and adjusted R-square have varying values in each year and every industry. However, the net profit coefficient has a positive value every year and every industry. This indicates that the net profit variable has the same direction of change with future cash flows. Additional Analysis Results of 1 hypothesis testing consistent with the regression results of the cash flow Prediction model 1. This indicates that there is no specific year of observation or industry that obscures observations in the year and other industries when all observations are used in a single regression model.

\subsection{Hypothesis Testing 2}

The cash flow prediction model 2 with the independent variable profit and control variables of the year and industry is presented in Table 6 below.

Table 6

Regression Result of Cash Flow Model (Prediction 2)

\begin{tabular}{l|c|c|c}
\hline Model & Coefficient & Standard Error & P. value \\
\cline { 2 - 4 } (constant) & 0.043 & 0.016 & 0.007 \\
$C I_{I T-1}$ & 0.201 & 0.022 & 0.000 \\
\hline F-Count $=13.98$ & R-square & $=0.0955$ \\
$P$. Value $=0.000$ & Adjusted R-square $=0.0887$ \\
\hline \multicolumn{2}{l}{ Variable bound: $A K O_{i t}$} \\
\hline \multicolumn{2}{l}{ Effects of years and industries have been controlled } \\
\hline
\end{tabular}

Description: $A K O=$ cash flow operation; $N I=$ net income; $C I=$ Profit comprehensive; $I=$ Company I; $t=\mathrm{t}$ period; $T-l=\mathrm{t}-1$ period. 
According to table 6, the cash flow Prediction Model 2 has an F-calculate of 13.98 and statistically significant $(\mathrm{p}<0.05)$, so it can be concluded that the regression model deserves use to predict future cash flows. In addition, the cash flow Prediction Model 2 has an adjusted value of $\mathrm{R} 2$ of 0.0887 . These values indicate that the cash flow of future operations can be explained by $8.87 \%$ of the comprehensive profit and control variables used in the research model.

The comprehensive profit has a coefficient of 0.201 and a statistically significant $(p<0.05)$. This suggests that a comprehensive profit has a significant association relationship with future cash flows. Thus, hypothesis 2 is supported. The results of this study correspond to the research results of Palea and Scagnelli (2016), which proves that the comprehensive profit has an association relationship with future cash flows. In addition, these results prove that information about all the resource changes an entity contained in a comprehensive income is beneficial to estimate the capabilities of the entity in generating future cash flows. The additional analysis of hypothesis 2 testing with regression tests per year is presented in table 7, and a regression test per industry is presented in the following table 8 .

Table 7

Results of regression of future cash flows and comprehensive earnings per year

\begin{tabular}{|c|c|c|c|c|c|c|}
\hline Description & & 2012 & 2013 & 2014 & 2015 & 2016 \\
\hline \multirow[t]{3}{*}{$C I_{I T-1}$} & Coefficient & 0.182 & 0.225 & 0.177 & 0.356 & 0.152 \\
\hline & P. value & 0.000 & 0.000 & 0.000 & 0.000 & 0.000 \\
\hline & Adj. R-Square & 0.110 & 0.167 & 0.121 & 0.105 & 0.051 \\
\hline $\mathrm{N}$ & & 235 & 250 & 261 & 466 & 523 \\
\hline
\end{tabular}

The dependent variable cash flow operations and industry variables have been controlled

Table 8

Results of regression of future cash flows and comprehensive profit per industry

\begin{tabular}{lcccc}
\hline Description & Key sectors & Manufacturing sector & $\begin{array}{l}\text { Service } \\
\text { Sector }\end{array}$ \\
\hline$C I_{I T-1}$ & Coefficient & 0.194 & 0.381 & 0.160 \\
& $P$. value & 0.000 & 0.000 & 0.000 \\
& Adj. $R$-Square & 0.070 & 0.152 & 0.28 \\
$\mathrm{~N}$ & 230 & 466 & 1039 \\
Industry variables have been controlled & & & \\
\hline
\end{tabular}


Based on table 7 and Table 8, the comprehensive income (Clit-1) from 2012 to 2016 is associated significantly $(\mathrm{p}<0.05)$ with future cash flows. The comprehensive and adjusted R-square profit coefficient of variables shows different values in each year and every industry. However, the comprehensive profit coefficient has a positive value every year in every industry. This indicates that the comprehensive profit variable has the same direction of change as the future cash flow variable. Additional analysis results in hypothesis 2 testing are consistent with the results of a regression model of cash flow prediction 2. This indicates that there is no specific year of observation or industry that obscures observations in the year and other industries when all observations are used in a single regression model.

\subsection{Hypothesis Testing (H3)}

The AIC calculation results are presented in the following table 9.

Table 9

Calculation result of AIC Model 1 and Model 2

\begin{tabular}{l|l}
\hline Model & AIC \\
\hline Model 1 & $-2,471,475$ \\
Model 2 & $-2,461,641$ \\
\hline
\end{tabular}

Relative likelihood $=0.0073$

According to table 9, it can be seen that Model 1 has a smaller AIC value compared to Model 2. Based on the relative likelihood value, Model 2 has a probability of 0.0073 times compared to model 1 in minimizing the loss of information to predict future cash flows. Thus, the three hypotheses are not supported, meaning that the comprehensive profit does not have a better ability than net profit in predicting future cash flows. These results were following the research of Dhaliwal, Subramanyam, and Trezevant (1999) and Jaweher \& Mounira (2013), which proved that comprehensive profit has no better ability than net profit in predicting future cash flows. From these results, it can be concluded that the comprehensive income has no better ability than net profit in predicting future cash flows. 
These results indicate that other comprehensive income information contained in a comprehensive income may not provide additional information for net profit in predicting future cash flows. To prove it is an additional analysis of other comprehensive income information relationships with future cash flows. The additional analysis of the 3-hypothesis testing is presented in Table 10 below.

Table 10

Results in regression of future cash flows and comprehensive profit components

\begin{tabular}{l|c|c|c}
\hline Model & Coefficient & Standard Error & P. value \\
\hline (constant) & 0.045 & 0.016 & 0.005 \\
$N I_{I T-1}$ & 0.223 & 0.023 & 0.000 \\
$O C I_{I T-1}$ & 0.016 & 0.063 & 0.805 \\
Variable years and industries have been controlled & $=0.1007$ \\
\hline F-Count $=13.76$ & R-square \\
$P$. Value $=0.000$ & Adjusted R-square $=0.0934$ \\
\hline \multicolumn{2}{l}{ Variable bound: $A K O_{i t}$}
\end{tabular}

Description: $A K O=$ cash flow operation; $N I=$ net income; $O c i=$ other comprehensive income; $I=$ Company I; $t=\mathrm{t}$ period; $T-1=\mathrm{t}-1$ period.

According to table 10, another comprehensive income variable (Ocilt-1) has a coefficient of- 0.016 and has no significant effect $(p \geq 0.05)$ against future cash flows. This suggests that other comprehensive income information does not have significant capability in predicting future cash flows.

The adjusted R-square regression model found in table 10 shows the value of 0.0934 , meaning that $9.34 \%$ of future cash flows can be explained by the research variables and the remainder described by other variables outside the study. The value is smaller than the adjusted $R$-square value (0.0939) of the Model 1 contained in table 3. This suggests that adding other comprehensive income information in the research model cannot help the model in describing future cash flows. On the other hand, when compared to the adjusted value of $R$-square (0.0887) of Model 2 contained in table 6 , the adjusted value of $R$-square in table 10 has a greater value. This suggests that comprehensive earnings cover the ability of net profit and other comprehensive income 
separately in predicting future cash flows. These results are consistent with the 3hypothesis testing expressed in the previous section.

\section{Conclusion, Limitatios and Suggestion}

Concerning H1, the results of this study show that net income is associated with future cash flows. Hypothesis 2 testing results show that comprehensive income is associated with future cash flows. Net profit and comprehensive earnings result in changes to the resources of an entity. Resource changes result in changes in the ability of the entity to carry out its operating activities. One of the things that resulted from the operation is cash flow. It can be concluded that the change of resources derived from a net profit or comprehensive profit is beneficial to measure the ability of an entity to generate future cash flows. Thus, the study was able to empirically prove that net profit and comprehensive profit had an association relationship with future cash flows.

Hypothesis 3 testing results in the study show that comprehensive income has no better ability than net profit in predicting future cash flows. Comprehensive income consists of net profit coupled with other comprehensive income. Other comprehensive income contains unrealized profit and load components. Comprehensive income is considered to have more information than net profit because it contains both realized and unrealized profit components so that it can describe the resource changes of an entity More complete. The presence of comprehensive income is expected to increase accrual profit capability in predicting future cash flows. However, the 3 hypothesis testing results could not indicate evidence of the matter. This result signifies that additional, comprehensive income information contained in a comprehensive income cannot help the net profit to measure the ability of an entity in generating future cash flows.

The limitations of this study are the inequality of elements that make up another comprehensive income added to the net profit to form a comprehensive profit. This is due to the different methods and conditions of each company in issuing financial statements. Therefore, it is advisable to be able to do some research in more detail by considering the elements contained in other comprehensive income. 


\section{Reference}

Atwood, T.J., Michael S. Drake, James N. Myers, and Linda A. Myers. (2011). Do earnings reported under IFRS tell us more about future earnings and cash flow? J. Account, Public Policy 30:103-121.

Brigham, Eugene F., Joel F. Houston, Hsu Jub-Ming, Kong Yoon Kee, and A. N. Bany-Ariffin. (2013). Essentials of Financial Management 3rd Edition. New Tech Park: Cengage Learning Asia Pte Ltd.

Burnham, Kenneth P., and David R. Anderson. (2004). Multimodel Inference, Understanding AIC, and BIC in Model Selection. Sociological Methods \& Research, Vol. 33, No. 2:261-304.

CFA Institute. (2015). Analyzing Bank Performance: Role of Comprehensive Income. Brussels: CFA Institute.

Chambers, Dennis, Thomas J. Linsmeier, Catherine Shakespeare, and Theodore Sougiannis. (2007). An Evaluation OF SFAS No. 130 Comprehensive income Disclosures. Review of Accounting Studies 12:557-593.

Dhaliwal, Dan, K. R. Subramanyam, and Robert Trezevant. (1999). Is Comprehensive income superior to net income as a measure of firm performance? Journal of Accounting and Economics 26:43-67.

Financial Accounting Standards Board. (2010). Statement of Financial Accounting Concepts No. 8. Norwalk: Financial Accounting Standards Board.

Gordon, Myron J. (1962). The Investment, Financing, and Valuation of the Corporation. Illinois: Richard D. Irwin, Inc.

Indonesian Institute of Accountants. (2017). Effective Financial Accounting standards as of January 1, 2017. Jakarta: Indonesian Accountant Association.

International Accounting Standards Board. (2010). The Conceptual Framework for Financial Reporting. London: IASB.

Jaweher, Bahloul, and Ben Arab Mounira. (2013). Quality of Net Income vs. Total Comprehensive Income in the Context of IAS/IFRS Regulation. International Journal of Finance \& Accounting Studies, Vol. 1 No. 2:17-34. 
Kieso, Donald E., Jerry J. Weygandt, and Terry D. Warfield. (2014). Intermediate Accounting IFRS Edition 2nd edition. China: John Wiley and Sons, Inc.

Kim, Myungsun, and William Kross. (2005). The Ability of Earnings to Predict Future Operating Cash Flows Has Been Increasing-Not Decreasing. Journal of Accounting Research, Vol. 43, No. 5:753-780.

Palea, Vera, and Simone Domenico Scagnelli. (2016). Earnings Reported under IFRS Improve the Prediction of Future on Cash Flows? Evidence from European Banks. Australian Accounting Review No. 00 Vol. 00.

Sekaran, Uma, and Roger Bougie. (2016). Research Methods for Business. West Sussex: John Wiley \& Sons Ltd.

Suwardjono. (2005). Financial Reporting Engineering accounting theory. Yogyakarta: BPFE.

Wolk, Harry L., James L. Dodd, and John Rozycki. (2013). Accounting Theory 8th edition Conceptual Issues in a Political and Economic Environment. Los Angeles: Sage.

Wooldridge, Jeffrey M. (2013). Introductory Econometrics: A Modern Approach, Fifth Edition. South-Western: Cengage Learning. 
The Indonesian Journal of Accounting Research - May, Vol. 22, No.2, 2019

intentionally blank 